\title{
A typology of elementary forms of human-nature relations: A contribution to the valuation debate
}

\author{
Roldan Muradian ${ }^{1}$ and Unai Pascual ${ }^{2,3,4}$ \\ 1. Universidade Federal Fluminense, Rio de Janeiro, Brazil; ${ }^{2 .}$ Basque Center for Climate Change (BC3), \\ Leioa, Spain; ${ }^{3}$ Basque Foundation for Science, Ikerbasque, Spain; ${ }^{4}$ Centre for Development and \\ Environment, University of Bern, Switzerland.
}

\begin{abstract}
This article aims to contribute to the debate about the role of relational values in environmental decision making. It puts forward a typology of 'human-nature relational models' as a contribution to the valuation debate. We argue that human-nature relational models, by taking insights from several disciplines and stressing the notion of cognitive frameworks, can be useful to understand core drivers of individual and social behavior behind environmental change and socio-environmental conflicts. A 'relational models' approach calls for understanding the diversity of cognitive frameworks conditioning our interaction with nature, with the ultimate goal of avoiding, mitigating, transforming and resolving socio-environmental conflicts.
\end{abstract}

\section{Introduction}

The ecosystem services framework (arguably a dominant paradigm for describing human-nature relations nowadays) reflects the emergence of an intellectual tradition that assumes that the best strategy to foster environmentalism is to appeal to instrumental values. According to this perspective, the role of valuation is to make these values visible, by making possible to capture and internalize them in decision making. Although the capacity of biocentric approaches to mobilize interest to conserve nature for its own sake is also acknowledged [1], the ecosystem services metaphor, while being a powerful communication tool, risks legitimizing an utilitarian and monist (based on a single measurement of value, e.g. money) discourse while downplaying the complex and manifold ways humans interact with nature and articulate the plurality of its values, and in particular the cultural and moral dimensions of such interactions ${ }^{1}[2,3$, $4,5]$.

Moving away from the use (and misuse) of value monism and fostering a transition to a pluralistic valuation approach is at the heart of the Intergovernmental Platform of Biodiversity and Ecosystem Services (IPBES) [5], which explicitly recognizes that valuation itself is a value laden process and that emphasis should be placed in social learning and integrating/bridging diverse values, especially in contested spaces. This is akin to the view of Bryan Norton [3], who from an ethical perspective concurs that in the quest for transformative change towards sustainability "what is needed is a method for

\footnotetext{
${ }^{1}$ We adopt a broad notion of nature, which includes either non-human entities, categories that composes similar entities (e.g. species) or more complex natural environments in which different types of non-human entities interact (e.g. ecosystems), referred to a particular geographical location or to a larger scale.
} 
evaluating change, a method that - unlike the current evaluative methods available today - can lead those with conflicting values to converge on actions that are agreed to improve unacceptable situations" (p.6). We agree with Norton that such an evaluative method can only come from pluralistic valuation approaches rather than from those that are based on value monism $[3,6]$.

As part of the debate around value pluralism, the dichotomy between intrinsic and instrumental values has been questioned, based on the proposition that it fails to resonate with many lay people. It is argued that in their decisions, people often consider the properties of the relationships they hold with nature rather than the inherent worth of nature itself or the benefits they derive from it in instrumental ways. These considerations, namely the preferences, principles and virtues associated with relationships with and responsibilities towards nature, as conducive to a 'good life', both meaningful and satisfying, is what has been coined as relational values [5;7]. The main objective of this article is to contribute to the theoretical debate around the notion of relational values by putting forward two propositions, namely:

1) It is possible to identify and categorize a finite number of discrete human-nature relational models (RMs). We propose an elementary typology of such RMs, each of them having their own 'grammar', encompassing several dimensions (see below for definitions for explanations).

2) What have been called 'instrumental values' correspond to one of those RMs, namely, 'utilization'. Similarly, intrinsic values are related to an alternative RM that allocates a particular set of rights to nature (e.g., 'wardship'). Lastly, the common use of the term 'relational values' may be associated with other RMs, such as 'stewardship' or 'ritualized exchange' (see explanations below, including descriptions in Table1). We propose that all three fuzzy categories of values (instrumental, relational and intrinsic) are indeed 'relational' in the sense that they are all derived from different cognitive frameworks that shape a given relationship with nature. From this point of view, the current -narrow- use of the term 'relational values', though intuitively appealing, might be confusing. Our typology of relational models links to (but it is not restricted to) the most common categories of values used in the valuation literature and calls for an improved classification and wording.

\section{Background literature and concepts}

Understanding the diversity of human-nature relations requires integrating insights from a variety of literatures and bridging disciplinary boundaries. We draw insights from social psychology (through the notion of social representations), psychological and cultural anthropology (through the concepts of relational or mental models and taboo trade-offs) and ecological economics (through the concepts of incommensurability of values and languages of valuation).

The theory of social representation stresses the links between individual cognition and social processes. ${ }^{2}$ It proposes that the ways we perceive and relate to nature, make sense of it, and order it, are influenced by cognitive processes that are to a large extent socially constructed [8]. This theory addresses the question of how human representations of reality, i.e., how the brain perceives, processes and gives sense to stimuli, are socially constructed. Some key tenets of this stream of thought are: (a) individual cognitive

\footnotetext{
${ }^{2}$ The theory of social representation is part of a French intellectual tradition in social psychology that started with Émile Durkheim, and to which Jean Piaget also belonged. It was consolidated with the work of Serge Moscovici.
} 
frameworks are collectively constructed and socially shared; but, (b) these frameworks are not deterministic and there is scope for individual variations; thus (c) social representations are enduring structures, but they also can be modified through individual will or social processes, e.g., through communication, social interaction, education and negotiation. Social representations influence the way people 'objectify' reality, thus determining what is perceived and what is not. Representations also influence the ways people anchor the received stimuli, i.e., how they systematize and classify them into pre-existing categories. Social representations also determine the reasoning behind causal relations, thereby influencing attitudes and behavior. Whenever there are sufficiently distinct and distant social representations of reality (shared by different social groups) conflicts may arise. The notion of 'framing'(referring to social representations as cognitive 'frameworks') is useful to analyze socioenvironmental conflicts [9]. This notion stresses that the confrontation of different (and hard to reconcile) cognitive frames held by disparate social groups is the underlying cause of many conflicts [10]. Hence, 're-framing' becomes a strategy for attempting conflict avoidance, mitigation, transformation and resolution $[11,12]$.

In psychological and cultural anthropology, taboo trade-offs $s^{3}$ refer to the difficulties faced by people when dealing with trade-offs among different types of value. They arise due to the fact that people are highly resistant to certain types of value trade-offs, due to cognitive incommensurability and moral stances. People often refuse to make trade-offs between different types of values because it would harm their self-image and their own standing within their social group [13]. Trade-offs are more likely to become morally impermissible whenever a situation requires people to articulate values using the social conventions framed by a given social representation of reality that is not considered to be theirs [13]. Similarly, in ecological economics, the terms 'strong incommensurability of values' [14] and 'lexicographic preferences' [14] are used to refer to situations when there are strong moral limits to the 'fungibility' of values (the extent to which different type of values can be exchanged, substituted and traded off). Whenever such situations arise, the reduction of values to a single common metric is likely to face resistance [16].

According to the Relational Models Theory, as elaborated initially by Alan Fiske [17], there are four elementary 'models' that frame social relationships: (1) in the communal sharing model, sociality is based on the perception that the set of persons involved in the relation have something in common that makes them socially equivalent; (2) authority ranking bases relations on asymmetrical, transitive and linearly ordered differences between people; (3) equality matching refers to relations around the allocation of additive exchange units, with even balance as the reference point; (4) in the market pricing model, social interaction is organized with reference to ratios and rates. These social RMs can be seen as cognitive frames or representations and may be conceived as discrete and universal. Each model is associated with a particular set of motivational and normative conventions that shape and give meaning to social relationships. What varies across cultures is in which situations the social relational models are applied. Prescriptions about which model should be applied in a particular situation is a social convention. Moreover, power relations influence which of the relational model is dominant in decision-making and which ones are deemed inferior or non-appropriate [18]. In this vein, power can be interpreted as having

\footnotetext{
${ }^{3} \mathrm{~A}$ taboo trade-off is an "explicit mental comparison or social transaction that violates deeply-held normative institutions of certain forms of relationship and of the moral-political values that derive from those relationships" ([13] p. 256).
} 
the capacity to enable, promote and/or impose a given relational model as 'common knowledge' via cultural practices, customs and habits [18].

\section{Human-nature relational models}

Human-nature interactions are configured by a complex arrangement of social conventions held by social groups in a particular period of time. Human-nature RMs are cognitive frames that give shape to relationships between people and nature. As in the case of Fiske's social relational models [16], we argue that there is also a finite number of cognitive frames underpinning human-nature RMs, and that they can be classified using discrete categories. The idea of human-nature RMs as cognitive frameworks that shape perceptions about nature and behaviour towards it is closely linked to the concept of "mental models", which are also applied to socio-environmental issues $[19 ; 20]$.

We propose seven elementary human-nature RMs, easily identified across cultures. While our typology is not necessarily exhaustive, we believe it covers the main cognitive structures underpinning human-nature relations, as described in a scattered way in the literature. Our classification has some similarities with the typology of values of nature proposed by Stephen Kellert [21]. But whereas Kellert's typology deals with what he calls "values" ${ }^{4}$, we consider that such classification mixes up relational models (e.g. utilitarian) with some dimensions of the grammar of such models (see below for a definition). For instance, the type of value he coins as 'symbolic', i.e., nature as a source of language and imagination, is present across the seven RMs we propose, though the use of language and symbols vary considerable across them.

We argue that individuals apply different RMs towards different 'entities' of the natural world or to the same entity in different situations, depending on the historical and social-ecological context of interaction. It is also possible that an individual shifts from one RM to another over time, as a result of learning, social interaction or communication. Human-nature RMs are shared by social groups as a way of group identification and mobilization, particularly so whenever socio-environmental conflicts arise.

Table 1 presents (and Figure 1 illustrates) seven human-nature RMs, each with their own grammar. The literature of social psychology dealing with relational models uses the term 'grammar' as a metaphor for 'the social conventions, rules, and norms that specify how and when and with respect to whom relational models apply' (p.633) [22]. We follow the same notion, and propose that the grammar of human-nature $\mathrm{RMs}$ is composed of at least five basic dimensions. These dimensions are different domains characterizing human-nature relationships. Each of them is governed by a particular set of social conventions.

The ontology dimension refers to what Descola [23] calls the 'mode of identification', namely, the cognitive structure or social representation that defines the boundaries between the self and the otherness. Here we identify three aspects within such dimension: (a) the degree to which society and nature are

\footnotetext{
${ }^{4}$ The categories in to which Kellert classifies values are: Aesthetic, dominionistic,humanistic, moralistic, naturalistic, negativistic, scientific, symbolic and utilitarian
} 
differentiated; (b) whether non-human entities are considered to have agency; and (c) how nature is positioned (e.g., inferior, equal or superior) vis-a-vis humans. Western societies in general and western science, in particular, are characterized by separating nature from people and human from non-human beings [24], which necessarily imposes limits to our cognitive capacity to interpret other knowledge systems and human-nature interactions in other cultures. Goal orientation refers to the overall societal goals guiding decision-making, and largely determines the evaluative criteria. Emotional drivers are a distinctive and unpreventable element of human-nature relations [25]. Here we understand emotions in a broad sense, as feelings and states of mind that steer behavior and decisions, as opposed to rational thinking. Practices refer to codified social conventions that set normative boundaries, particularly about the allocation of rights and responsibilities. They dictate what can and cannot be done in a particular relational setting based on dominant moralities. Lastly, the main mode of interaction summarizes the way the relationship is concretized or operationalized.

\section{[INSERT FIGURE 1]}

Below we briefly explain the main features characterizing the elementary typologies of human-nature RMs:

Detachment is dominated by indifference towards nonhuman entities, either because they are not perceived or because they are considered irrelevant. This relational model might be the consequence of ignorance and lack of experience. Some authors have warned that current technological and urbanization trends might be associated with a distancing of humans from nature [26], resulting in major emotional, attitudinal and behavioral changes in our interaction with it [27]. The cognitive consequences of declining contact with the natural world and the extent to which contemporary urban life leads to alienation towards nature is a subject that has not received sufficient academic attention. We hypothesize that the rising use of information technology and urbanization will increasingly be associated with the perception of the bulk of natural entities as abstract and distant objects, rendering them irrelevant or invisible.

Domination derives from a sense of human entitlement over nature and fear (sense of threat). Nature is seen as a space to be conquered, as a category opposed to 'civilization'. Hostility and annihilation are distinctive under this mode of interaction. We might associate this model with 'predatory naturalism', as described by Descola [23], characterized by both a clear society-nature distinction and an antagonistic vision towards nature, which is perceived as an obstacle to 'progress'. The clearing of large tracts of forest in the European Middle Age [23] and the mass devastation of forests during the colonial time in Brazil [28] can be seen as processes driven by this relational model.

Devotion is characterized by hierarchical relations. Natural entities are conceived as having agency and divine properties, above humans. Religious rituals and taboos are the basis of social conventions that give meaning to and shape human-nature relationships. For example, in Southern Indian sacred groves biodiversity conservation is not a goal in itself, but a byproduct of complex religious practices closely intertwined with the local ecology [29; 30].

In the Stewardship model, the natural entity is perceived as not having agency but there is no clear-cut subject-object distinction, since humans are seen as part of (and dependent on) nature. This interdependency is the basis for human responsibility towards nature. Such sense of responsibility is expressed in nature-centered management rules and self-imposed behavioral limits. The metaphor of Gaia 
[31] and the ethical precepts behind the agro-ecological movement could seen as reflections of this relational model [32].

Wardship shares with the stewardship model the sense of human restraint for the sake of nature's protection, but it has a preference for either wilderness and pristine states or control over natural entities. This relational model leads to the promotion of protected natural spaces from which human activities should be removed, or in caring and managing animal or vegetal species for non-utilitarian purposes. It can also be associated with the notion of benevolent patronage bestowed by humans on natural entities [23]. In this model, humans hold responsibility for the custody or nature, which is seen as a distinctive entity with its own (intrinsic) rights.

The utilization model underlies the appropriation of nature's goods and services, mostly via extraction and consumption. It is dominated by a utilitarian logic, which might lead either to an exploitative or preservationist use of nature, and often to the commoditization of its properties. It is strongly associated with instrumental values [33]. This model underpins the green economy and the ecosystem services metaphors [34]. The core elements are the utilitarian stand towards the natural environment and a clear society-nature distinction.

Ritualized exchange arises in situations where humans allocate agency to a natural entity, and engage in an exchange not governed by considerations of proportionality and ratios but by ritualized codes of equality, balance and reciprocity. For example, traditionally the Maya group Itza (from Guatemala) assume that in order to exploit natural resources through plant collection, hunting, agriculture, etc. they had to 'pay' the guardian spirits (yum-il) through ritualized food offerings [35]. The Tukanoan indigenous group of Colombia are reported to follow the principle of strict equivalence and reciprocity between humans and non-humans, who share a natural environment that has a finite amount of 'generic vitality'. Exchanges must take place so as to compensate non-humans for the share of vitality that has been diverted from them in the process of food procurement by humans. It is believed that both humans and non-humans contribute jointly, through reciprocal exchanges, to the general equilibrium of the cosmos $[36 ; 23]$.

\section{[INSERT TABLE 1]}

The grammar of each of the seven relational models is reflected in the combination of criteria for evaluation and the discourse used for political mobilization, both derived from social conventions and moral motives. This is what in ecological economics has been called 'languages of valuation' [36]. Which model is expected to be applied in a given situation is a social convention that might vary substantially among cultural backgrounds and/or among social groups. Applying a particular relational model to situations that are expected - given prevailing social conventions - to be governed by a different model often leads to moral outrage and taboo trade-offs.

Socio-environmental conflicts are generally characterized by situations where there is not an overarching principle (common among stakeholders) for setting social goals. Confronted social groups around a socioenvironmental conflict typically make use of their own discourses, e.g., markets vs rights, and promote their desired relational model in specific contexts while trying to gain social legitimacy. When the RMs held by different social groups are incommensurable, aggregation of values becomes extremely challenging or impossible. In such situations, conflicts can become intractable and no socially optimal 
solution may be found. In such cases however, conflict resolution through social learning may still be possible. Learning would imply being exposed to different RMs, each with their own grammar and language of valuation, and being able to empathize and negotiate meanings, social goals and decisionmaking mechanisms [38].

Importantly, RMs influence not only how the problem is perceived (cognitive framing), but also the notion of justice held, as well as the considered policy options and discourses for social mobilization [39]. Cognitive divergence caused by discrepancy of RMs is at the root of the intractability of many socioenvironmental conflicts. People may not only disagree about the intervention at stake or how the problem is conceived, but also about how to deal with such disagreements. For example, in conflicts around mining projects with potentially high environmental impacts on surrounding ecosystems, local populations often prefer a local referendum as a decision making tool, while mining companies frequently prefer the adoption of a compensation rationale [40]. The key point is that such choices do not only reflect different strategies in conflict management, but most importantly different ways of relating to nature and languages of valuation.

\section{Implications for valuation}

There are various key implications of taking the perspective of human-nature RMs in valuation.

First, adopting a relational model approach implies the need to recognize the limits to the social acceptance of trade-offs and aggregation of wellbeing indicators given potential incommensurability among RMs.

Second, valuation approaches need to embrace pluralism to grasp the diversity of RMs, and to understand each of them using their own 'grammars', aiming for social learning.

Third, the main goal of valuation should be to identify and disentangle the (not always explicit) RMs involved in socio-environmental conflicts. Rather than trying to 'get the price right' (by means of eliciting people's economic preferences and aggregating them) the objective should be to 'map the RMs among social groups', in order to foster social learning under diverse and competing cognitive frameworks about nature.

Fourth, in situations where the incommensurability of the RM is a contentious issue, attention should be given to procedural aspects and the quality of the decision-making process. In such situations, agreements about the process would be a necessary source of legitimacy for any adopted decision, since the final outcome might likely be not satisfactory for all the parties involved.

Fifth, any valuation process implies a relation with the subject being valued, and therefore, strictly speaking, all values emanate from relational models. What varies is the type of relational model on which the different ways of articulating values are manifested. 
Last but not least, the complexity entailed in the drivers of environmental change and socioenvironmental conflicts cannot be dealt with using a single grammar or language of valuation. Transformation to sustainability cannot simply rely on showing the hidden instrumental values of nature. Instead, the role of valuation should be to foster awareness about the ways in which socio-environmental interactions depend on different and often competing human-nature RMs, especially in contexts of uneven social power relations. Transforming people's relations towards nature first requires addressing how humans cognitively frame their relationships with it, and the intricate mechanisms involved in changing such framings.

\section{Acknowledgements}

We are grateful to two anonymous referees and to Rachelle Gould for their very valuable comments on the manuscript.

\section{References}

1. Kumar, P. The Economics of Ecosystems and Biodiversity: Ecological and Economic Foundations. Earthscan. London; 2010.

2. Barnaud, C., Antona, M: Deconstructing ecosystem services: Uncertainties and controversies around a socially constructed concept. Geoforum 2014, 53: 133-123.

3. Norton, B. 2015. Sustainable Values, Sustainable Change: A Guide to Environmental Decision Making. University of Chicago Press. Chicago, 319 pp. 2015.

4. Díaz, S., U. Pascual, M. Stenseke, B. Martín-López, R.T. Watson, Z. Molnár, R. Hill,K.M.A. Chan, et al. Assessing nature's contributions to people. Science 2018, 359(6373):270-272

5. (**) Pascual, U., Balvanera, P., Díaz, S., Pataki, G., Roth, E., Stenseke, M., Watson, R.T., Dessane, B.E., et al.: The value of nature's contributions to people: the IPBES approach. Curr Opin Environ Sustain 2017, 26-27: 7-16.

This paper synthesizes the position of IPBES with regards the importance of multiple conceptualizations of values and advocates for value pluralism.

6. Jacobs, S., Dendoncker, N., Martín-López, B., Barton, D. N. D. N., Gomez-Baggethun, E., Boeraeve, F. et al (2016). A new valuation school: Integrating diverse values of nature in resource and land use decisions. Ecosystem Services, 22, 213-220.

7. (**) Chan, K., Balvanera, P., Benessaiah, K., Chapman, M., Díaz, S., Gómez-Baggethun, E., Gould, R., Hannahs, N. et al.: Why protect nature? Rethinking values and the environment. PNAS 2016, 113 (6): 1462-1465.

In this paper, a definition of relational values is provided and this is put in context in the intrinsic vs. instrumental value debate.

8. (*) Moscovici, E., Duveen, G.: Social Representations: Explorations in social psychology. Polity Press. Cambridge, 313 pp. 2000.

This book synthesizes the theory of social representations 
9. (*) Brummans, B., Putnam, L., Gray ,B., Hanke, R., Lewicki, R., Wiethoff, C. : Making sense of intractable multiparty conflict: A study of framing in four environmental disputes. Comm Mon 2008, 75(1): 25-51.

This paper explores the relationship between cognitive framing and the intractability of socioenvironmental conflicts

10. Davis, C., Lewicki, R.: Environmental conflict resolution: Framing and intractability- An introduction. Environ Pract 2003, 5(3): 200-206.

11. Putnam, L.,Burgess, G., Royer, R.: We can't go on like this: Frame changes in intractable conflicts. Environ Pract 2003, 5(3): 247-255.

12. Asah, S., Bengston, D., Wendt, K., Nelson, K.: Diagnostic reframing of intractable environmental problems: Case of a contested multiparty public land-use conflict. J Env Man 2012, 108: 108119.

13. (**) Fiske, A., Tetlock, P.: Taboo trade-offs: Reactions of transactions that transgress the spheres of justice. Polit Psych 1997, 18(2): 255-297.

This article explains taboo trade-offs as clashes between social relational models

14. Martinez-Alier, J., Munda, G., O'Neill, J.: Weak comparability of values as a foundation for ecological economics. Ecol Econ 1998: 277-286.

15. Spash, C., Hanley, N.: Preferences, information and biodiversity preservation. Ecol Econ 1995, 12 (3): 191-208.

16. Wegner, G., Pascual, U.: Cost-benefit analysis in the context of ecosystem services for human wellbeing: A multidisciplinary critique. G Env Ch 2011, 21(2): 492-504.

17. (**) Fiske, A.: The elementary forms of sociality: Framework for a unified theory of social relations. Psych Rev 1992, 99(4): 689-723.

This seminal articles sets the basis for the theory of social relational models

18. Ishihara, I, Pascual, U.: Social capital in community level environmental governance: A critique. Ecol Econ 2009, 68(5): 1549-1562.

19. Jones, N., Ross, H., Lynam, T., Perez, P., Leitch, A.: Mental Models: An interdisciplinary synthesis of theory and methods. Ecol Soc 2011, 16(1): 46.

20. (*) Bang, M., Medin, D., Atran, S.: Cultural mosaics and mental models of nature. PNAS 2007, 104 (35): 13868-13874.

This paper uses the notion of mental models to explain different ways to relate to the forest by culturally disparate social groups inhabiting the same region

21. Kellert, S.: Experiencing nature: Affective, cognitive and evaluative development in children. In Kahn, P., Kellert, S. (Eds.) Children and Nature: Psychological, Sociocultural, and Evolutionary investigations. MIT Press, Cambridge, U.S., 117-151 pp. 2002.

22. Koerner, A.: Models of relating - not relationship models: Cognitive representations of relating across interpersonal relationship domains. J. Soc. Per. Relat. 2006, 23 (4): 629-653.

23. Descola, P.: Constructing natures: Symbolic ecology and social practice. In: Descola, P., Pálsson, G. (Ed.). Nature and Society: Anthropological Perspectives.. Routledge. London, 82-102.1996. 
24. Murdoch, J.: Inhuman/nonhuman/human: actor-network theory and the prospects for a nondualistic and symmetrical perspective on nature and society. Env Plan D 1997, 15: 731-756.

25. Buijs, A, Lawrence, A.: Emotional conflicts in rational forestry: Towards a research agenda for understanding emotions in environmental conflicts. For Pol Econ 2013, 104-111.

26. Atran, S., Medin, D.: The native man and the cultural construction of nature. MIT Press. Cambridge, 333 pp.2008.

27. Soga, M., Gaston, K.: Extinction of experience: the loss of human-nature interactions. Front Ecol Environ 2016, 14(2): 94-101.

28. Pádua, J.A. : Um Sopro de Destruição:Pensamento Político e Crítica Ambiental no Brasil escravista (1786-1888). Jorge Zahar Editora. Rio de Janeiro, 318 pp.2002.

29. Kent, E.: Sacred groves and local gods: Religion and environmentalism in South India. Oxford University Press. New York, 256 pp.2013.

30. Ormsby, A.: Analysis of local attitudes toward the sacred groves of Meghalaya and Karnataka, India. Con Soc 2013, 11(2): 187-197.

31. Pigliucci, M. : Why Gaia? Eth Env 2014, 19 (2): 117-124.

32. Norder, L., Lamine, C., Bellon, S., Brandenburg, A.: Agroecology: polysemy, pluralism and controversies. Amb Soc 2016, 13 (3): 1-20.

33. Klain, C., Olmsted, P., Chan, K., Satterfield, T. Relational values resonate broadly and differently than intrinsic or instrumental values, or the New Ecological Paradigm. PlosOne 2017.

34. Costanza, R., de Groot, R., Braat, L., Kubiszewski, I., Fioramonti, L., Sutton, P., Farber, S., Grasso, M.: Twenty years of ecosystem services: How far have we come and how far do we still need to go? Ecos Serv 2017, 28: 1-16.

35. Le Guen, O., Iliev, R., Lois, X., Atran, S., Medin, D.: A garden experiment revisited: intergenerational change in environmental perception and management of the Maya Lowlands, Guatemala. J Roy Anth Inst 2013, 19: 771-794.

36. Jackson, J.: The Fish people: Linguistic exogamy and Tukanoan Identity in the Northwest Amazon. Cambridge University Press. Cambridge, 308 pp. 1983.

37. Martinez-Alier, J.: The Environmentalism of the Poor.. Edward Elgar. London, 328 pp.2003.

38. Pahl-Wostl, C.: Towards sustainability in the water sector: The importance of human actors and processes of social learning. Aquat Sci 2002, 64: 394-411.

39. Schulz, C., Martin-Ortega, J., Ioris, A., Glenk, K.: Applying a value landscape approach to conflicts in water governance: The case of Paraguay-Paraná waterway. Ecol Econ 2017, 138: 4755.

40. Walter, M, Urkidi, L. Community consultations: Local responses to large-scale mining in Latin America. In: De Castro, F., Hogenboom, B., Baud, M. (Eds). Environmental Governance in Latin America. Palgrave Macmillan. New York, 287-325 pp.2016. 


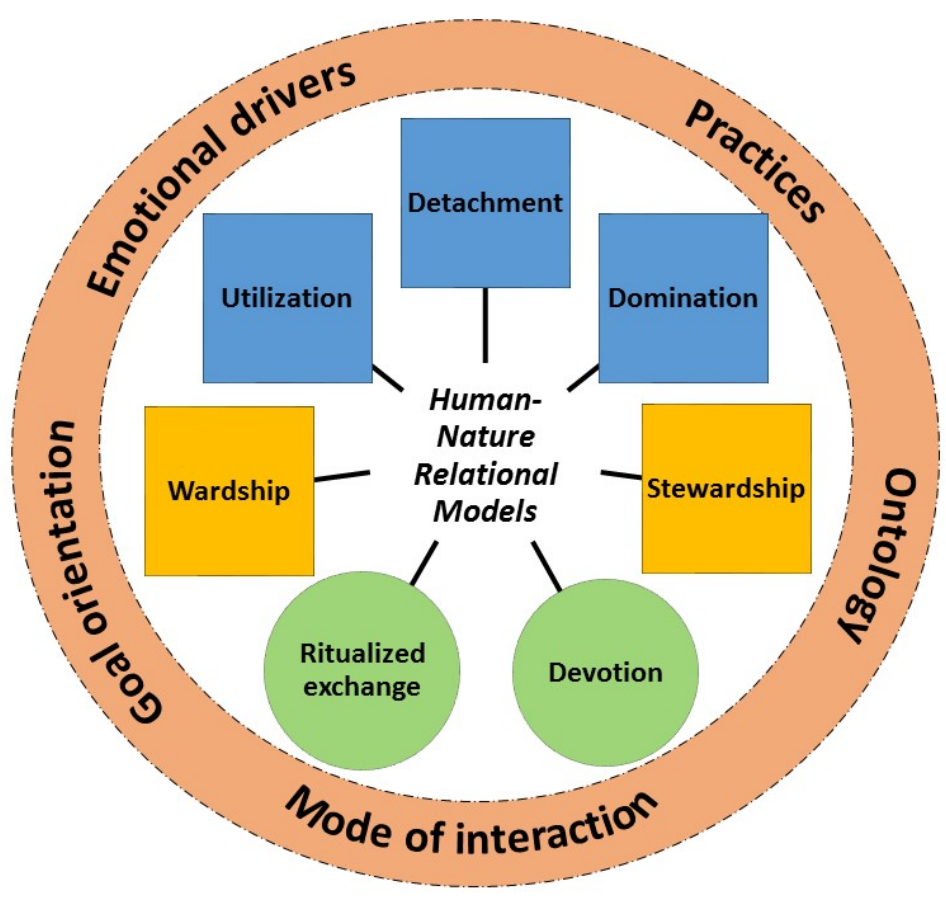

Figure 1. Human-nature relational models: There are seven elementary relational models characterized by an underpinning grammar (outer circle), composed of various dimensions: ontology, mode of interaction with nature, goal orientation of the interaction, emotional drivers behind the social representation of nature and practices. People and nature can be sharply differentiated (boxes) or not (circles), and nature can be perceived as having agency (green), positioned in inferior or invisible ways (blue) or with intrinsic rights or as equal (yellow). Each relational model articulates values in a different way. 
Table 1: An elementary typology of human-nature relational models

\begin{tabular}{|c|c|c|c|c|c|c|c|}
\hline & \multicolumn{3}{|c|}{ Ontology (nature of the subject) } & \multirow[b]{2}{*}{ Goal orientation } & \multirow[b]{2}{*}{$\begin{array}{c}\text { Emotional } \\
\text { drivers }\end{array}$} & \multirow[b]{2}{*}{ Practices } & \multirow[b]{2}{*}{$\begin{array}{l}\text { Main mode of } \\
\text { interaction }\end{array}$} \\
\hline $\begin{array}{l}\text { Relational } \\
\text { model }\end{array}$ & $\begin{array}{l}\text { Clear } \\
\text { society- } \\
\text { nature } \\
\text { distinction }\end{array}$ & $\begin{array}{l}\text { Nature } \\
\text { entity } \\
\text { with } \\
\text { agency }\end{array}$ & $\begin{array}{l}\text { How nature is } \\
\text { positioned vis- } \\
\grave{a} \text {-vis humans }\end{array}$ & & & & \\
\hline Detachment & Yes & No & $\begin{array}{l}\text { Nature } \\
\text { inexistent } \\
\text { (invisible) }\end{array}$ & $\begin{array}{l}\text { Preference for urban-and } \\
\text { technological spaces. Nature } \\
\text { perceived as not important }\end{array}$ & Indifference & Absence of codified practices & Isolationism \\
\hline Domination & Yes & No & $\begin{array}{l}\text { Hierarchical } \\
\text { relation: Nature } \\
\text { as subordinated } \\
\text { (inferior) }\end{array}$ & $\begin{array}{l}\text { Preference for human } \\
\text { control over nature. Nature } \\
\text { perceived as a threat }\end{array}$ & Fear & $\begin{array}{l}\text { Rules and norms based on } \\
\text { human entitlement (for } \\
\text { appropriation/annihilation of } \\
\text { nature) and superiority }\end{array}$ & $\begin{array}{l}\text { Destruction } \\
\text { (hostility) }\end{array}$ \\
\hline Devotion & No & Yes & $\begin{array}{l}\text { Hierarchical } \\
\text { relation: Nature } \\
\text { as deity } \\
\text { (superior) }\end{array}$ & $\begin{array}{l}\text { Preference for situations that } \\
\text { are believed to be favorable } \\
\text { for the deities. Nature } \\
\text { perceived as sacred }\end{array}$ & $\begin{array}{l}\text { Seek of } \\
\text { transcendence } \\
\text { Obligation }\end{array}$ & $\begin{array}{l}\text { Sacredness yielding religious } \\
\text { practices (rituals including } \\
\text { taboos) }\end{array}$ & Worship \\
\hline Stewardship & No & No & $\begin{array}{l}\text { Humans as part } \\
\text { of Nature }\end{array}$ & $\begin{array}{l}\text { Preference for human } \\
\text { restraint in order to respect } \\
\text { nature. Nature perceived as a } \\
\text { comprehensive system that } \\
\text { encompasses humans. }\end{array}$ & $\begin{array}{l}\text { Sense of } \\
\text { belonging, } \\
\text { Identity } \\
\text { Care }\end{array}$ & $\begin{array}{l}\text { Rules and norms about nature- } \\
\text { centered management and self- } \\
\text { imposed behavioral limits }\end{array}$ & $\begin{array}{l}\text { Livelihoods } \\
\text { integration into } \\
\text { nature }\end{array}$ \\
\hline Wardship & Yes & No & $\begin{array}{l}\text { Nature as a } \\
\text { separate entity } \\
\text { with intrinsic } \\
\text { rights }\end{array}$ & $\begin{array}{l}\text { Preference for pristine } \\
\text { spaces or conditions. Nature } \\
\text { perceived as a separate } \\
\text { entity to be protected. }\end{array}$ & $\begin{array}{l}\text { Aesthetic } \\
\text { experience } \\
\text { Care } \\
\text { Peacefulness }\end{array}$ & $\begin{array}{l}\text { Rules and norms where } \\
\text { delimitation of pristine spaces } \\
\text { or conditions, and biocentrism } \\
\text { (intrinsic rights of nature) } \\
\text { prevail }\end{array}$ & $\begin{array}{l}\text { Preservation of } \\
\text { wilderness } \\
\text { Benevolent } \\
\text { patronage }\end{array}$ \\
\hline
\end{tabular}




\begin{tabular}{|c|c|c|c|c|c|c|c|}
\hline $\begin{array}{l}\text { Ritualized } \\
\text { exchange }\end{array}$ & No & Yes & Nature as equal & $\begin{array}{l}\text { Preference for equality. } \\
\text { Nature perceived as an } \\
\text { interactive agent }\end{array}$ & Obligation & $\begin{array}{l}\text { Rules and norms based on the } \\
\text { sense of partnership }\end{array}$ & $\begin{array}{l}\text { Partnership } \\
\text { Seek of balance }\end{array}$ \\
\hline Utilization & Yes & No & $\begin{array}{l}\text { Nature as a } \\
\text { separate entity } \\
\text { with no } \\
\text { intrinsic rights }\end{array}$ & $\begin{array}{l}\text { Preference for maximizing } \\
\text { benefit-cost ratios. Nature as } \\
\text { a source of goods and } \\
\text { services and disservices. }\end{array}$ & $\begin{array}{l}\text { Needs } \\
\text { satisfaction }\end{array}$ & $\begin{array}{l}\text { Rules based on rational } \\
\text { calculation and } \\
\text { orientation }\end{array}$ & $\begin{array}{l}\text { Utilization } \\
\text { (exploitative or } \\
\text { preservationist) }\end{array}$ \\
\hline
\end{tabular}

